\title{
Oral Health-related Quality of Life: Current Status and Future Implications
}

\author{
Neha Agrawal ${ }^{1}$, Anshul Aggarwal ${ }^{2}$, Amit K Garg ${ }^{3}$, Narinder Dev Gupta ${ }^{4}$, Rajendra K Tewari ${ }^{5}$, Juhi Gupta ${ }^{6}$
}

\begin{abstract}
Quality of life (QoL) is relatively new but a rapidly growing notion in the discipline of dental or oral health. People's perception of the mode in which oral diseases, conditions, and treatments influence their symptoms, functions, and well-being is referred to as oral health-related quality of life (OHRQoL). The effects of oral health and diseases on QoL are the area of research that examines the functional, psychological, social, and economical consequences of oral disorders. The outcomes of OHRQoL have evolved as a means to comprehend and mold not only the clinical practice, dental research, and dental education but also that of the community at large. The idea of "oral health-related quality of life" incarcerates the aim of the new perspective, that is, the ultimate target of dental care, primarily good oral health, should no longer simply be seen as the absence of caries or periodontal disease but also the patient's mental and social well-being should be considered equally and ensure access of cure for everyone.
\end{abstract}

Keywords: Oral health, Patient outcomes, Psychosocial factors, Quality of life.

Journal of Oral Health and Community Dentistry (2021): 10.5005/jp-journals-10062-0101

\section{INTRODUCTION}

Patient-centered treatment necessitates clinicians to not only diagnose the physical diseases but also to enhance the patients' psychosocial well-beings. Consequently, health-related quality of life (HRQoL), which evaluates four broad fields, namely physical health, psychological well-being, social relationships, and environment, has evolved as a focal point of research in recent years.

Quality of life is a recent concept in the field of health and very much so with respect to dental or oral health. It is a very subjective concept. Mount and Scott linked the assessment of it to appraising the beauty of rose: What so ever measurements are made (e.g., color, smell, form, etc.), the entire beauty of the rose is never described. ${ }^{2}$ The World Health Organization (WHO) defined it as "The condition of life resulting from the combination of the effects of the complete range of factors such as those determining health, happiness (including comfort in the physical environment), and a satisfying occupation, education, social and intellectual attainment, freedom of action, justice, and freedom of expression." ${ }^{3}$

The term "Health Related quality of life" has been defined as a multidimensional concept capturing people's perceptions about aspects that are important in their everyday lives. For example, "Healthy People 2010" refers to "a personal sense of physical and mental health and the ability to react to factors in the physical and social environment." ${ }^{4}$ Patrick and Erickson identified and provided more formal definitions in the multiple dimensions representing HRQoL. ${ }^{5}$ The list consists of conventional clinical measures (e.g., diagnosis) and epidemiologic indices (e.g., mortality) that were particularly discarded by the sociomedical indicator's movement, which rectified an over dependence on traditional medial measures. ${ }^{6}$ Consequently, the majority of efforts for assessing health-related QoL focuses on the first six concepts mentioned in Table 1.

The QoL measures are just the adjunct to the other measures that are used to assess the outcomes of a disease, not a replacement for them.

\begin{abstract}
1,4 Department of Periodontics and Community Dentistry, Dr ZA Dental College, Aligarh Muslim University, Aligarh, Uttar Pradesh, India

2,6 Department of Oral Pathology and Radiology, Dr ZA Dental College, Aligarh Muslim University, Aligarh, Uttar Pradesh, India

${ }^{3}$ Department of Conservative Dentistry and Endodontics, KD Dental College, Mathura, Uttar Pradesh, India

${ }^{5}$ Department of Conservative Dentistry and Endodontics, Dr ZA Dental College, Aligarh Muslim University, Aligarh, Uttar Pradesh, India

Corresponding Author: Neha Agrawal, Department of Periodontics and Community Dentistry, Dr ZA Dental College, Aligarh Muslim University, Aligarh, Uttar Pradesh, India, Phone: +91 7895335770, e-mail: dr.n_ agrawal@yahoo.co.in

How to cite this article: Agrawal N, Aggarwal A, Garg AK, et al. Oral Health-related Quality of Life: Current Status and Future Implications. J Oral Health Comm Dent 2021;15(2):87-91.

Source of support: Nil

Conflict of interest: None

Table 1: Concepts and domains of HRQoL

\begin{tabular}{|c|c|}
\hline Domain & Characteristics \\
\hline Opportunity & $\begin{array}{l}\text { Social or culture handicap and } \\
\text { individual resilience }\end{array}$ \\
\hline Health perceptions & $\begin{array}{l}\text { Satisfaction with health and general } \\
\text { health perceptions }\end{array}$ \\
\hline Functional status-social & $\begin{array}{l}\text { Limitations in usual roles, integration, } \\
\text { contact, and intimacy }\end{array}$ \\
\hline $\begin{array}{l}\text { Functional status- } \\
\text { psychologic }\end{array}$ & Affective states and cognitive capacity \\
\hline Functional status-physical & Activity restriction and fitness \\
\hline Impairment & $\begin{array}{l}\text { Complaints, signs, self-reported disease, } \\
\text { psychological measures, and diagnosis }\end{array}$ \\
\hline Death and duration of life & Mortality, survival, and longevity \\
\hline
\end{tabular}
\end{abstract}

Data from Patrick and Erickson ${ }^{5}$

() The Author(s). 2021 Open Access This article is distributed under the terms of the Creative Commons Attribution 4.0 International License (https://creativecommons. org/licenses/by-nc/4.0/), which permits unrestricted use, distribution, and non-commercial reproduction in any medium, provided you give appropriate credit to the original author(s) and the source, provide a link to the Creative Commons license, and indicate if changes were made. The Creative Commons Public Domain Dedication waiver (http://creativecommons.org/publicdomain/zero/1.0/) applies to the data made available in this article, unless otherwise stated. 


\section{Oral Health-Related Quality of Life}

Oral health-related quality of life (OHRQoL) is a comparatively novel and hastily growing tool that is being used world wide. ${ }^{4}$ Many researchers have found that the basis of the conception of HRQoL and OHRQoL is the perception of health as complete physical, mental, and social well-being rather than just the absence of the disease and infirmity as stated in the definition of WHO. ${ }^{7-9}$ This shift was observed in the latter half of the twentieth century, and it was due to the change in the value system of industrialized civilizations from money-oriented values that focused on financial stability and self-assurance to values that focused on self-determination and self-actualization. ${ }^{10,11}$

From the literature review, it was observable that the concept of OHRQoL came into being only in the early 1980s in comparison to general HRQoL that emerged in the late 1960s. The reason for the same could be the feeble recognition of the effects of oral diseases on QoL, as a few decades back the researchers discarded the notion that oral diseases could be related to general health. ${ }^{12-14}$ Davis stated that except for cancers and the pain of oral diseases, oral health does not have any effect on the social life of people, it is just a cosmetic matter. ${ }^{12}$ Likewise, other researchers also discovered oral diseases to be insignificant problems that seldom lead to exclusion from work. ${ }^{13,14}$

It was only in the late 1970 the OHRQoL notion started to emerge when oral diseases were found to have an impact on the social roles. ${ }^{15,16}$

Clinical measures of oral diseases, for example, dental caries or periodontal diseases, were unable to capture the notion of the mental and social well-being of a person required to determine health as described by WHO. This need led to the development of an alternative health status measures that would assess the physical, psychological, and social impact of oral conditions on an individual. ${ }^{17}$

\section{CONCEPT OF OHRQOL}

The concept of "oral health-related quality of life" describes the aim of a new point of view, that is, the ultimate goal of oral healthcare, primarily good oral health, should no longer simply be seen as the absence of caries or periodontal disease but also the patient's mental and social well-being should be considered equally and ensure access of cure for everybody. ${ }^{9}$

\section{Dimensions of OHRQoL}

OHRQoL is "a multidimensional construct that reflects (among other things) people's comfort when eating, sleeping, and engaging in social interaction; their self-esteem; and their satisfaction with respect to their oral health. ${ }^{18}$

Common dimensions in OHRQoL instruments along with the examples of each are given in Figure 1. It included the traditional aspects as well as factors such as the social and emotional wellbeing of an individual. Thus, OHRQoL instrument assesses both the positive and negative dimensions of life. ${ }^{19}$

\section{Uses of Quality of Life Measures in Clinical Practice ${ }^{8}$}

- Identifying and screening the unidentified problems

- Prioritizing problems

- Improving communication

- Assisting in clinical decision-making

- Observing changes/responses to treatment.

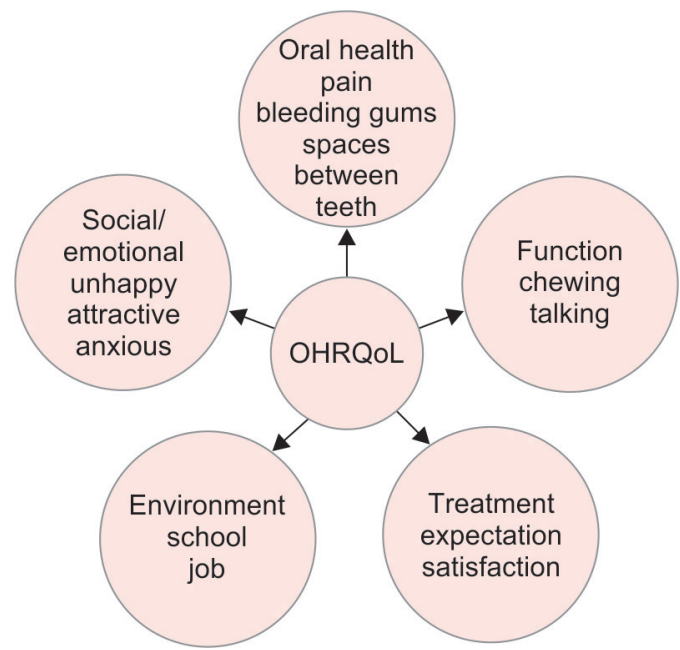

Fig. 1: Dimensions comprising OHRQoL

\section{Required Properties of Measures to be Used in Clinical Practice ${ }^{8}$}

- Validity

- Reproducibility

- Appropriateness and acceptability

- Sensitive to change

- Interpretability.

\section{SIGNIFICANCE OF OHRQOL}

OHRQoL is an important philosophical and practical concept and a health priority. "QoL issues are now being used to decide public health policy." ${ }^{17}$ Oral health is the mirror of general health, and it affects life of all; OHRQoL measures are being used in research to study varied populations comprising oral cancer patients, ${ }^{20}$ toddlers with early childhood caries, ${ }^{21}$ or children with craniofacial abnormalities. $^{22}$

OHRQoL measures are increasingly being used to improve the provision of care for patients in clinical practice, dental research, and dental education, and prioritizing the need of the community at large. ${ }^{8}$

OHRQoL has improvised the clinical practice by making the clinician more responsible for the patient as they do not treat only teeth and gums, but human beings. OHRQoL concerns have led to better use of dental services in terms of practicing good oral hygiene, having regular check-ups, and spending more money on esthetic dental care. ${ }^{17}$

Founded on the exemplary patient-centered, biopsychosocial approach to oral healthcare, OHRQoL has become vital to dental research. ${ }^{19}$ All the successful researches, be it a fundamental scientific research, clinical trials, or community research, have an impact on patients' QoL. Specifically, at the community level research, the concept of OHRQoL has improvised the oral healthcare and access to care. ${ }^{17}$

Similarly, OHRQoL measures have a role in educating people about their oral health. People act more responsibly when they understand that oral diseases have an impact on their general health and QoL not merely affecting their teeth or gums. ${ }^{17}$

OHRQoL is one feature of individuals HRQoL, and these two concepts are inseparable as oral health is one facet of the overall 
health of an individual. Consequently, concerns connected to one's overall HRQoL are relevant to those linked to OHRQoL and vice versa. ${ }^{23}$ Some recent studies have measured the impact of general ${ }^{24}$ and specific aspects of oral health, as the use of prostheses, ${ }^{25}$ surgical treatments, ${ }^{26}$ parafunctional habits, ${ }^{27}$ and dental pain, ${ }^{28}$ among others, on QoL in different samples, found the association of oral conditions evaluated on the factors of HRQoL of patients.

\section{Measurement of OHRQoL}

As more and more researches are being carried out in the field of QoL, more numbers of health measures are emerging. Various measures are being used to analyze patient's perceptions regarding the impact of a variety of chronic conditions. Before using any measure to assess the QoL, a number of theoretical issues should be considered. ${ }^{29}$

In relation to public health, oral health can be measured at the macro level using the societal measures of oral health status, which reveals that oral disease generates a significant burden of poor health, mainly among deprived people. ${ }^{30}$

Researchers after recognizing the importance of OHRQoL have developed several measurement instruments. Slade has specified three categories of OHRQoL measure, ${ }^{7}$ and they are social indicators, global self-ratings of OHRQoL, and multiple item questionnaires of OHRQoL.

The most common and widely used method to measure OHRQoL is multiple item questionnaires. Several QoL instruments have been developed by researchers exclusively to measure oral health, and their number is increasing to meet the current requirements. These measures can also be classified into generic instruments versus specific instruments. Generic instruments measure complete oral health, while specific instruments are specialized to assess specific oral health conditions like dental anxiety, cancers of head and neck region, and dentofacial malformation, or to appraise specific populations, such as children. ${ }^{31-33}$

Also, OHRQoL instruments differ from each other according to the number of questions (items) and the format of questions and responses. At the First International Conference on Measuring Oral Health, 10 OHRQoL instruments have been systematically tested to evaluate their psychometric properties, such as validity, reliability, and responsiveness. ${ }^{34}$ Table 2 presents the 10 instruments, their dimensions, number of questions, a pattern of a question, and response scheme of each measure. ${ }^{8}$

Table 2: OHRQoL questionnaires

\begin{tabular}{|c|c|c|c|c|}
\hline Measures & Dimensions used & $\begin{array}{l}\text { Number of } \\
\text { questions }\end{array}$ & Example of question & Response format \\
\hline Sociodental scale & $\begin{array}{l}\text { Chewing, talking, smiling, } \\
\text { laughing, pain, and appearance }\end{array}$ & 14 & $\begin{array}{l}\text { Are there any types of foods you have } \\
\text { difficulties chewing? }\end{array}$ & Yes/no \\
\hline $\begin{array}{l}\text { RAND dental } \\
\text { health index }\end{array}$ & Pain, worry, and conversation & 3 & $\begin{array}{l}\text { How much pain have your gums and teeth } \\
\text { caused you? }\end{array}$ & $\begin{array}{l}4 \text { categories: "not at } \\
\text { all" to "great deal" }\end{array}$ \\
\hline $\begin{array}{l}\text { General oral health } \\
\text { assessment index }\end{array}$ & $\begin{array}{l}\text { Chewing, eating, social contact, } \\
\text { appearance, pain worry, and } \\
\text { self-consciousness }\end{array}$ & 12 & $\begin{array}{l}\text { How often did you limit the kinds or amounts } \\
\text { of foods you eat because of problem with your } \\
\text { teeth or denture? }\end{array}$ & $\begin{array}{l}6 \text { categories: "always" } \\
\text { to " never" }\end{array}$ \\
\hline $\begin{array}{l}\text { Dental impact } \\
\text { profile }\end{array}$ & $\begin{array}{l}\text { Appearance, eating, speech, } \\
\text { confidence, happiness, and social } \\
\text { life relation ship }\end{array}$ & 25 & $\begin{array}{l}\text { Do you think your teeth or denture have a good } \\
\text { effect (positive), a bad effect (negative), or no } \\
\text { effect on your feeling comfortable? }\end{array}$ & $\begin{array}{l}3 \text { categories: good } \\
\text { effect, bad effect, } \\
\text { and no effect }\end{array}$ \\
\hline $\begin{array}{l}\text { Oral health impact } \\
\text { profile }\end{array}$ & $\begin{array}{l}\text { Function, pain, physical disability, } \\
\text { psychologic disability, social } \\
\text { disability, and handicap }\end{array}$ & 49 & $\begin{array}{l}\text { Have you had difficulty chewing foods because } \\
\text { of problems with your teeth, mouth, or } \\
\text { denture? }\end{array}$ & $\begin{array}{l}5 \text { categories: "very } \\
\text { often" to "never" }\end{array}$ \\
\hline $\begin{array}{l}\text { Subjective oral } \\
\text { health status } \\
\text { indicator }\end{array}$ & $\begin{array}{l}\text { Chewing, speaking, symptoms, } \\
\text { eating, communication, and social } \\
\text { relationships }\end{array}$ & 42 & $\begin{array}{l}\text { During the last year, how often have (dental } \\
\text { problems) caused you to have difficulty } \\
\text { sleeping? }\end{array}$ & $\begin{array}{l}\text { Various, depending } \\
\text { on question factor }\end{array}$ \\
\hline $\begin{array}{l}\text { Oral health quality } \\
\text { of life inventory }\end{array}$ & $\begin{array}{l}\text { Oral health, nutrition, self-rated } \\
\text { oral health, and overall quality of } \\
\text { life }\end{array}$ & 56 & $\begin{array}{l}\text { Two part questions: (A) How important is it for } \\
\text { you to speak clearly? (B) How happy are you } \\
\text { with your ability to speak clearly? }\end{array}$ & $\begin{array}{l}\text { Part A: } 4 \text { categories } \\
\text { (not at all important } \\
\text { to very important) } \\
\text { Part B: } 4 \text { categories } \\
\text { (unhappy to happy) }\end{array}$ \\
\hline $\begin{array}{l}\text { Dental impact on } \\
\text { daily living }\end{array}$ & $\begin{array}{l}\text { Comfort, appearance, pain, daily } \\
\text { activity, and eating }\end{array}$ & 36 & $\begin{array}{l}\text { How satisfied you have been on the whole with } \\
\text { your teeth in the last } 3 \text { months? }\end{array}$ & $\begin{array}{l}\text { Various, depending } \\
\text { on question format }\end{array}$ \\
\hline OHRQoL & $\begin{array}{l}\text { Daily activity, social activity, and } \\
\text { conversation }\end{array}$ & 3 & $\begin{array}{l}\text { Have problem with your teeth or gums affected } \\
\text { your daily activity such as work or hobbies? }\end{array}$ & $\begin{array}{l}6 \text { categories: "all the } \\
\text { time" to "none of the } \\
\text { time" }\end{array}$ \\
\hline $\begin{array}{l}\text { Oral impacts on } \\
\text { daily performances }\end{array}$ & $\begin{array}{l}\text { Performance in eating, } \\
\text { speaking, oral hygiene, } \\
\text { sleeping, appearance, and } \\
\text { emotion }\end{array}$ & 9 & $\begin{array}{l}\text { Four part questions: (A) In the past } 6 \text { months, } \\
\text { have (dental problems) caused you any } \\
\text { difficulty in eating and enjoying food? (B) Have } \\
\text { you had this difficulty on a regular basis or for } \\
\text { a period or spell? (C) During the last } 6 \text { months, } \\
\text { how often have you had this difficulty? (D) Using } \\
\text { a scale from } 0 \text { to 5, which number reflects what } \\
\text { impact the difficulty in eating and } \\
\text { enjoying food had on your daily life? }\end{array}$ & $\begin{array}{l}\text { Various, depending } \\
\text { on question format. }\end{array}$ \\
\hline
\end{tabular}




\section{Current Status and Future ReCOMMENDATIONS}

Recently, QoL measures have gained worldwide attention and are being used globally. Quality rather than just the duration of years we live has become a focus of healthcare and health research. QoL evaluation acknowledged enormous interest with the release of the Healthy People 2010, health promotion and disease prevention program. The objectives of this initiative were to enhance quality, years of a healthy life, and to eradicate health inequality. ${ }^{8}$

Major research recommendations of the workshop were:

- Systematic use of suitable operational measures needs to be carried out to identify and conceptualize oral health needs.

- Additional research needs to be performed to conceptualize and assess oral health as it affects the overall health.

- Considerations need to be given to various factors influencing oral health outcomes

- An evaluation of "Outcomes for whom" needs to be carried out to ascertain the character and extent of indicators

- Following methodological matters needs to be considered, for example, sensitivity, specificity, reliability, validity, and development of outcome measure for longitudinal studies, and suitability of measures as affected by the duration of the event. ${ }^{8}$

- Explicit research recommendations that concentrate on social, psychological, and economic influence of oral conditions and treatment,

- Analyzing the sensitivity of generic health status indicators for people with oral diseases

- Investigating whether generic instruments such as sickness illness profile could be adapted for use in people with oral conditions

- Addressing methodological problems as well as comparing responses to various subjective oral health indicators in the same population or patient groups explore

- Exploring the relationships between clinical indicators and subjective indicators determining disease effect

- Measuring the importance of subjective indicators in clinical trials of existing/new intervention/technologies

- Examining measures and indicators among all age-groups. ${ }^{8}$

\section{Conclusion}

The challenge that poor oral health and low oral healthcare utilization create is mainly due to the inequitable access to care. This challenge deepens and becomes a public health policy issue due to prevailing economic and healthcare conditions and reduced healthcare expenditure. The relation between oral health conditions and QoL can be effectively used to convey the importance of good oral health and equal access to care to the policymakers. Sociocultural and psychological factors need to be considered while measuring the needs, outcomes, and clinical practice to match with the ever-increasing treatment alternatives and variability among patient groups. Comparing QoL across various treatment groups may assist the decision-making for patients, healthcare providers, and policymakers, thus improving the overall health of the public.

\section{References}

1. Sun L, Wong HM, McGrath CPJ. The factors that influence oral health-related quality of life in 15 -year-old children. Health Qual Life Outcomes 2018;16(1):19. DOI: 10.1186/s12955-018-0847-5.
2. Higginson I, Carr AJ. Using quality of life measure in clinical setting Br Med J 2001;322(7297):1297-1300. DOI: 10.1136/bmj.322.7297.1297.

3. Concepts and methods of community based initiatives. World Health Organization Regional office for the Eastern Mediterranean Cairo, 2003. Who-EM/CBI/016/E/G Distribution General.

4. US department of health and human services. Healthy people 2010. Washington DC: United States Department of Health and Human Services, Government Printing Office; 2000. p. 8.

5. Patrick DL, Erickson P. Health status and health policy. Quality of life in health care evaluation and resource allocation. New York: Oxford University Press; 1993.

6. Elison J. Towards sociomedical health indicators. Soc Indic Res 1974;1:59-71. DOI: 10.1007/BF00286421.

7. Slade GD. Oral health-related quality of life: assessment of oral healthrelated quality of life. In: Inglehart MR, Bagramian RA, editors. Oral health-related quality of life. Illinois: Quintessence Publishing Co. Inc.; 2002.

8. Gift HC, Atchison KA, Dayton CM. Conceptualizing oral health and oral health related quality of life. Soc Sci Med 1997;44(5):601-608. DOI: 10.1016/s0277-9536(96)00211-0.

9. Inglehart MR, Bagramian RA. Oral health related quality of life: an introduction. In: Inglehart MR, Bagramian RA, editors. Oral healthrelated quality of life. Illinois: Quintessence Publishing Co. Inc.; 2002.

10. Inglehart RF. The silent revolution. Changing values and political styles among Western Publics [Online]. Princeton, New Jersey: Princeton University Press; 1977.

11. Inglehart RF. Cultural shift in advanced industrial society. Princeton, New Jersey: Princeton University Press; 1990.

12. Davis P. Compliance structure and the delivery of health care: the case of dentistry. Soc Sci Med 1976;10(6):329-335. DOI: 10.1016/00377856(76)90079-2.

13. Dunnell K, Cartwright A. Medicine takers, prescribes and hoarders. London: Rutledge and Kegan; 1972. p. 241-243.

14. Gerson LW. Expectations of "sick role" ex-emptions for dental problems. J Can Dent Assoc 1972;38(10):370-372. PMID: 4507763.

15. Cushing AM, Sheiham A, Maizels S. Developing sociodental indicators - the social impact of dental diseases. Community Dent Health 1986;3(1):3-17.

16. Ettinger RL. Oral diseases and its effect on the quality of life. Gerodontics 1987;3(3):103-106.

17. Al Shamrany M. Oral health-related quality of life: a broader perspective. East Mediterr Health J 2006;12(6):894-901.

18. DHHS. Oral health in America: a report of the surgeon general. Rockville, Maryland: US Department of Health and Human Services, National Institute of Dental and Craniofacial Research, National Institute of Health; 2000; p. 7.

19. Sischo L, Broder HL. Oral health-related quality of life: what, why, how, and future implications. J Dent Res 2011;90(11):1264-1270. DOI: 10.1177/0022034511399918.

20. Ship JA. Oral health-related quality of life in patients with oral cancer. In: Inglehart MR, Bagramian RA, editors. Oral health-related quality of life. Carol Stream, IL: Quintessence Publishing Co., Inc.; 2002. p. 153-168.

21. Filstrup SL, Briskie D, da Fonseca M, et al. Early childhood caries and quality of life: child and parent perspectives. Pediatr Dent 2003;25(5):431-440.

22. Broder HL. Children's oral health-related quality of life. Community Dent Oral Epidemiol 2007;35(1):5-7. DOI: 10.1111/j.1600-0528. 2007.00400.x.

23. Rozier RG, Pahel BT. Patient and population reported outcomes in public health dentistry: oral health-related quality of life. Dent Clin N Am 2008;52(2):345-365. DOI: 10.1016/j.cden.2007.12.002.

24. Leão MM, Garbin CA, Moimaz SA, et al. Oral health and quality of life: an epidemiological survey of adolescents from settlement in Pontal do Paranapanema/SP. Brazil Cien Saude Colet 2015;20(11):3365-3374. DOI: 10.1590/1413-812320152011.00632015.

25. Cano-Gutiérrez C, Boorda MG, Arciniegas AJ, et al. Edentulism and dental prostheses in the elderly: impact on quality of life measured 
with EuroQol - visual analog scale (EQ-VAS). Acta Odontol Latinoam 2015;28(2):149-155. DOI: 10.1590/S1852-48342015000200009.

26. Mustafa AA, Raad K, Mustafa NS. Effect of proper oral rehabilitation on general health of mandibulectomy patients. Clin Case Rep 2015;3(11):907-911. DOI: 10.1002/ccr3.373.

27. Carvalho AM, Lima MD, Silva JM, et al. Bruxism and quality of life in schoolchildren aged 11-14. Cien Saude Colet 2015;20(11):3385-3393. DOI: 10.1590/1413-812320152011.20772014.

28. Yang SE, Park YG, Han K, et al. Dental pain related to quality of life and mental health in South Korean adults. Psychol Health Med 2015;10(1):1-12. DOI: 10.1080/13548506.2015.1098781.

29. Finbarr Allen P. Assessment of oral health related quality of life. Health Qual Life Outcomes 2003;1:40. DOI: 10.1186/1477-7525-1-40.

30. Bennadi $D$, Reddy CVK. Oral health related quality of life. J Int Soc Prev Community Dent 2013;3(1):1-6. DOI: 10.4103/2231-0762.115700.
31. Terrell JE et al. Head and neck cancer-specific quality of life: instrument validation. Arch Otolaryngol Head Neck Surg 1997;123(10):1125-1132. DOI: 10.1001/archotol.1997.01900100101014.

32. Cunningham SJ, Garratt AM, Hunt NP. Development of a condition-specific quality of life measure for patients with dentofacial deformity: reliability of the instrument. Community Dent Oral Epidemiol 2000;28(3):195-201. DOI: 10.1034/j.16000528.2000.280305.x.

33. Jokovic A, Locker $D$, Stephens $M$, et al. Validity and reliability of a questionnaire for measuring child oral-health-related quality of life. J Dent Res 2002;81(7):459-463. DOI: 10.1177/154405910208100705.

34. Slade GD, Strauss RP, Atchison KA, et al. Conference summary: assessing oral health outcomes-measuring health status and quality of life. Community Dent Health 1998;15(1):3-7. PMID: 9791607. 